\title{
Lymarenko 0. MODELING OF HEAT TRANSFER PROCESSES IN VENTILATED ENCLOSING STRUCTURES IN STATIONARY CONDITIONS
}

Одним із шляхів підвищення енергоефективності житлово-комунального підприємства та вирішення проблеми обігріву приміщень є будівництво «пасивних будинків», які містять елементи конструкцій ефективно сприймаючих енергію сонячної радіачї. Об’єктом дослідження є «Пасивний Будинок», що представляє собою будівлю, в якій тепловий комфорт (ISO 7730) досягається виключно за рахунок додаткового попереднього підігріву (або охолодження) маси свіжого повітря. Це необхідно для підтримання в приміщеннях повітря високої якості, без його додаткової рециркуляиії.

Проведено аналіз прочесів теплообміну у вентильованих огороджуючих конструкціях та проаналізовано розрахункові методи їх проектування. Застосування технологій пасивного сонячного обігріву приміщень в кліматичних умовах Украӥни дозволить забезпечити до 50 \% потреб у теплоті.

Визначено, що рух зовнішнього повітря у ВОК (відкриті огороджуючі конструкціі) вздовж стіни будинку призводить до втрат тепла, однак повітря у вентильованому шарі буде запобігати утворенню та скупченню конденсату. Це дозволить в зимовий період зберегти термічні властивості зовнішнього шару ізоляиї будинку, зменшити витрати тепла на опалення та запобігти утворенню та розвитку грибкової плісняви.

Досліджено особливості процесів теплообміну в будівельних конструкціях з вентильованими каналами. На основі проведеного аналізу розрахункових методів проектування ВОК можна стверджувати, що класична методика оцінки теплообмінних процесів базується на рівняннях теплового балансу повітря для нескінченно малого об’єму $d x$. Але при використанні цього рівняння неможливо врахувати розподіл променевого та конвективного потоків тепла, а також оцінити вплив втрат енергї.

У роботі запропоновано математичну модель, яка дозволить визначати зміни температури повітря вздовж вентильованого шару огороджуючих конструкцій та кількісно оцінювати надходження або втрати тепла у приміщення в холодну пору року.

Ключові слова: стаціонарний теплообмін, вентильовані огороджуючі конструкиї, стіна Тромба, тепловий потік.

\section{Introduction}

Today, in the context of the financial and energy crisis in the world, more attention is paid to reducing, efficient consumption of traditional fuel and energy resources and reducing harmful emissions into the environment. The most energy-consuming are the technological processes associated with the production, transportation and consumption of thermal energy [1, 2]. According to the State Statistics Committee of Ukraine, communal energy consumes $44 \%$ of energy resources, accounting for about $30 \%$ of the total fuel consumption in the country. The main causes that lead to unjustifiably large heat losses in housing and communal services are the imperfection of existing building structures, as well as the lack of individual metering devices and energy management systems. Much of the heat loss in homes during the heating season is due to the difference in the temperatures of the indoor and outdoor air (transmission heat losses through the outer enclosing structures).

That is why research of modern trends and methods of energy saving in buildings is topical. One of the ways to improve the energy efficiency of housing and utilities and solve the problem of heating the premises is the construction of «Passive houses».

«Passive houses» consist of structures, utilizing the energy of solar radiation as a result of air exchange pro- cesses (heating up to the temperature of the indoor air of cold outside air entering through leaks or open windows and doors).

To create a correct mathematical model, it is necessary to investigate experimentally the processes of heat exchange of air in ventilated channels, on the basis of the obtained data, to create the corresponding equations that specified the mathematical model.

\section{The object of research and its technological audit}

One of the ways to increase the energy efficiency of the housing and communal enterprise and solve the problem of heating the premises is building «Passive houses» that contain elements of structures that effectively absorb the energy of solar radiation.

The object of research is the «Passive house», which is a building in which thermal comfort (ISO 7730) is achieved solely by additional preheating (or cooling) of the fresh air mass. This is necessary to maintain high quality air in the rooms, without additional recirculation.

The criteria for a Passive house in Europe are:

- the specific heat consumption for heating, determined by the calculations in the «Passive House Planning Package» (PHPP) program, should not exceed $15 \mathrm{kWh} /\left(\mathrm{m}^{2} \cdot\right.$ year $)$ or heating load $\leq 10 \mathrm{~W} \cdot \mathrm{m}^{2}$; 
- special requirements for building cooling demand $\leq 15 \mathrm{~kW} \cdot \mathrm{h} /\left(\mathrm{m}^{2} \cdot\right.$ year $)$;

- the annual period of overheating (room temperature above $25^{\circ} \mathrm{C}$ ) $\leq 10 \%$;

- the result of the leak test $(\mathrm{N} 50) \leq 0.6$ changes in air/h;

- the total primary energy consumption for all household needs (heating, hot water and electric energy) should not exceed $\leq 120 \mathrm{kWh} / \mathrm{m}^{2} \cdot$ year).

The design of houses for such technologies in the EU countries was the most widespread and allowed to provide at the expense of the sun $97 \%$ of the requirements for heating. In the conditions of Ukraine from the use of the technology of passive solar heating of premises it is possible to hope for providing up to $50 \%$ of the requirements for heat.

\section{The aim and objectives of research}

The aim of the work is creation of a mathematical model of heat exchange during air movement in ventilated enclosing structures to determine the change in air temperature and to quantify the heat input to the room for the cold season.

To achieve this aim, it is necessary to perform the following tasks:

1. To determine the main element of open ventilated channels.

2. To establish the main causes that lead to unjustifiably large heat losses in the housing and communal sector.

3. To investigate the features of heat exchange processes in building structures with ventilated channels.

\section{Research of existing solutions of the problem}

The main conditions for the implementation of effective passive solar technology are [2-5]:

- high level of thermal insulation of premises;

- heat utilization of the ventilation air;

- orientation of buildings in such way that in the summer to ensure the absence of overheating, and in winter, on the contrary, as much as possible to let the sun in the room.

In construction, the enclosing structures (ES) with open and closed layers of air are widely used. Recently, open (ventilated) structures are especially interesting for architects.

Problems of municipal heat and power engineering of Ukraine and ways of its modernization were dealt with by the authors of $[1,2]$.

Work on creating an experimental energy-efficient house of passive type «zero energy» belongs to the author [3].

The features of heat transfer through a multilayer structure, in the non-stationary regime, are considered in [4].

Ways of energy efficiency in the passive house and ventilated wall panels are dealt with by the authors of $[5,6]$.

The improvement of the passive solar house with the Trombe wall is done by scientists [7-9].

In general, in Ukraine scientists carried out significant analytical work in the field of development and introduction of innovative energy products in the country [1-5]. The experience of developed countries [8-12] can serve as a basis for Ukraine, if there is a basis for putting domestic energy potential.

\section{Methods of research}

Open enveloping structures are widely used in the construction of walls, ventilated facades, horizontal partitions (attics, floors). ES is also effective in structural building elements for passive solar heating (Trombe wall). An example of such application is the through-pass ES element, which serves as a channel for supplying air to the room, and the outside air is heated while moving along the interlayer and is fed into the room. In the walls, it is possible to use ES for the purpose of single, double or multiple air movement [6].

The main element of the ES is the outer wall of the house, in which the air layer is between the insulation layer and the facade slabs. The movement of outdoor air in the ES along the wall of the house leads to heat loss, but air in the ventilated layer will prevent the formation and accumulation of condensate. This will allow in winter to maintain the thermal properties of the outer layer of insulation at home, reduce the cost of heat for heating and prevent the formation and development of fungal mold. During the summer period, the room will be warmed up less, due to the cooling of the wall with air intake.

Passive heating of the house is carried out by solar radiation - a regenerative energy source. One of the most famous structural elements of the passive solar heating system is the Trombe wall (Fig. 1) [7].
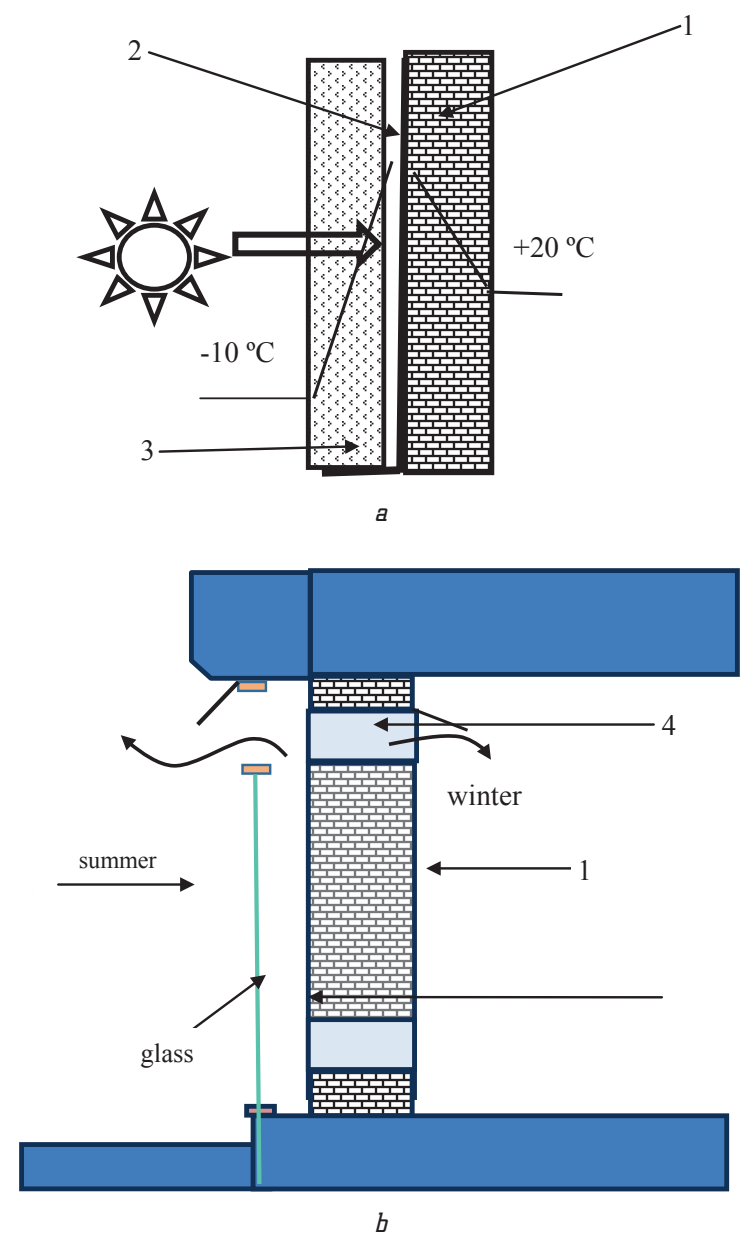

Fig. 1. Scheme: $a$ - Trombe wall; $b$ - modified Trombe wall $[8,9]$ 1 - massive wall; 2 - dark surface; 3 - glass; 4 - shutter 
The massive wall 1 of the dark surface 2 is separated from the atmospheric air by a glass overlap. In the interval between the glass ceiling and the wall, air moves. If the Trombe wall has holes in the upper and lower parts of the structure, then in the case where they are closed, convection is absent:

$$
t_{x}=\frac{\left(k_{I} t_{I}+k_{E} t_{E}\right)+\left[t_{0}\left(k_{I}+k_{E}\right)-\left(k_{I} t_{I}+k_{E} t_{E}\right)\right] e^{\frac{k_{I}+k_{E}}{W c} x}}{k_{I}+k_{E}},
$$

where $t_{0}$ - the temperature of the air entering the channel; $t_{I}, t_{E}$ - air temperature (internal and external); $k_{I}, k_{E}-$ the heat transfer coefficients, respectively, from the internal air to the air in the ES and from the air in the ES to the outside air; $W$ - air consumption; $x$ - the coordinate.

Similar studies are performed in [13]:

$$
\left(k_{I}+k_{E}\right)\left(t_{C}-t_{x}\right) d x=W c d,
$$

where $t_{C}$ - constant temperature, which is reached at a certain distance, depending on the conditions of heat exchange in the structure (with constant heat exchange):

$$
t_{C}=t_{I}-\frac{1}{k_{I} R_{0}}\left(t_{I}-t_{E}\right)=\frac{k_{I} t_{I}+k_{E} t_{E}}{k_{I}+k_{E}} .
$$

The main task of the research is determination of the distance at which the air temperature in the channel should have a constant value.

After separating the variables and integrating the difference equation (3) in the given interval, let's obtain:

$$
\begin{aligned}
& \frac{t_{x}-t_{C}}{t_{0}-t_{C}}=e^{-\frac{k_{I}+k_{E}}{c W} x}, \\
& t_{x}=\frac{k_{I} t_{I}+k_{E} t_{E}}{k_{I}+k_{E}}-\left[\frac{k_{I} t_{I}+k_{E} t_{E}}{k_{I}+k_{E}}-t_{0}\right] e^{-\frac{k_{I}+k_{E}}{c W} x} .
\end{aligned}
$$

As a result of mathematical transformations, equation (5) takes the form of equation (1):

$$
t_{x}=\frac{\left(k_{I} t_{I}+k_{E} t_{E}\right)+\left[t_{0}\left(k_{I}+k_{E}\right)-\left(k_{I} t_{I}+k_{E} t_{E}\right)\right]}{k_{I}+k_{E}} e^{-\frac{k_{I}+k_{E}}{c W} x} .
$$

In $[14-16]$ there are some inaccuracies in the formulation of the values of thermal resistances. In the enclosing structures, supports are defined as the thermal resistances of parts of structures from the inner surface to the air layer, and from the air layer to the outer surface of the enclosure:

$$
t_{y}=\frac{\left(k_{I} t_{I}+k_{E} t_{E}\right)+\left[\tau_{0}\left(k_{I}+k_{E}\right)-\left(k_{I} t_{I}+k_{E} t_{E}\right)\right]}{k_{I}+k_{E}} e^{-\frac{C_{C}\left(k_{I}+k_{E}\right)}{c W} h_{y}},
$$

where $t_{y}-$ the air temperature in the ventilated channel (same as $t_{x}$ ); $\tau_{0}$ - the air temperature at the entrance to the channel (same as $\left.t_{0}\right) ; h_{y}$ - the distance from the air inlet to the channel (same as $x$ ); $C_{C}$ - the conversion coefficient, in [16] there is no description of the physical meaning and value of this coefficient.

Analyzing equation (1), it is possible to draw the following conclusions:

- one of the main disadvantages of this equation is that the heat exchange processes are represented as one common physical process;
- in the case of convective heat transfer, the heat flow is proportional to the difference in temperature in the first stage, but in the case of heat exchange by radiation, to the fourth power, according to the Stefan-Boltzmann law;

- when combined heat transfer by convection and radiation is difficult to determine the quantitative contribution of each component in the overall process of heat exchange. Therefore, it is very difficult to answer the question what would be more effective: increasing the heat return through the elevation plate or intensifying the air heating process and ES (this can't be confirmed by calculation);

- equation (1) does not determine how the choice of the structural solution or the material from which the ES elements consist of affects the heat flow, in addition, it is impossible to determine the heat transfer coefficient; - equation (1) does not correctly reflect the physical meaning of heat exchange processes. The thermal balance of the air layer is represented by the equation (2), meaning that the flow of heat from the air into the room is completely transmitted to the air in the channel. In fact, the physical process looks different: heat passes from the air into the room, while heating the internal surface of the channel, which in turn heats the movable air in the channel, as well as the outer surface of the channel.

\section{Research results}

In the cold period of the year, the heat flow $Q_{i}$ is directed from the room to the outside. The heat flow heats the ES inner surface $p_{1}$. The heated inner surface, as a result of convective heat transfer, gives off heat to the air that moves along it, and also radiates heat to the surface $p_{2}\left(Q_{1-2}\right)$. Since the outer air moves at the ES, which has a lower temperature than the surface temperatures, it will heat up both inside and outside and at the outer surface. Thus, the thermal radiation coming to the outer surface is partly used for heating the air in the channel, and partly goes to the external environment $Q_{e}$. The physical model of the heat transfer process for a horizontal structure is similar. In the formulation of a mathematical model using the equation of heat balance air (6), and assume that the temperature of the surface $p_{1}$ and $p_{2}$ depends on the variable $x$. The processes are considered in the model, let's consider stationary.

The heat balance equation for each surface is based on the physical model (Fig. 2, 3).

Since the heat flow by convection is expended on heating the air, let's write the equation of the air balance:

- moves near the surface $p_{1}$ :

$$
h c_{1}\left(T_{1}(x)-T a_{1}(x)\right) d x=c G_{1} d T a_{1}
$$

- moves near the surface $p_{2}$ :

$$
h c_{2}\left(T_{2}(x)-T a_{2}(x)\right) d x=c G_{2} d T a_{2},
$$

where $d T a_{1}, d T a_{2}$ - the change in air temperature at an elementary distance $d x$, respectively, at the surface $p_{1}$ and $p_{2}$; $G_{1}, G_{2}$ - air flow near each surface; $c$ - air heat capacity;

- the equation of the thermal balance of the surface $p_{1}$ :

$$
Q_{i}=Q_{1-2}+Q_{c_{1}-a_{1}}
$$


- the equation of the thermal balance of the surface $p_{2}$ :

$Q_{1-2}=Q_{c_{2}-a_{2}}+Q_{e}$

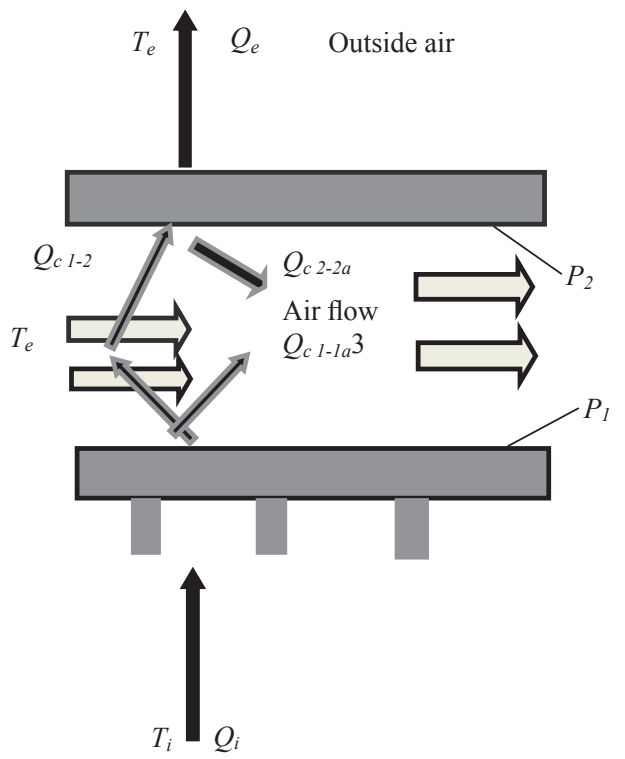

Fig. 2. Diagram of heat flow distribution in horizontal open enclosing structures

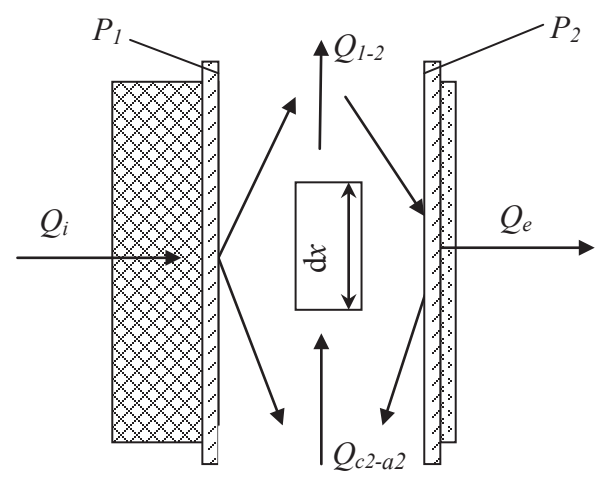

Fig. 3. Diagram of heat flow distribution in vertical open enclosing structures

Heat flow $Q_{i}$ to the inner surface:

$Q_{i}=k_{1}\left(T_{i}-T_{1}(x)\right) d x$.

Heat flow $Q_{e}$ from surface $p_{2}$ to outside air:

$$
Q_{e}=k_{2}\left(T_{2}(x)-T_{e}\right) d x \text {. }
$$

In equations (11), (12) $k_{1}, k_{2}$ - the heat transfer coefficients from the internal air to the surface $p_{1}$ and from the surface $p_{2}$ to the outer surface:

$$
k_{1}=\frac{1}{\frac{1}{\alpha_{1}}+\sum_{i=1}^{n} \frac{\delta_{i}}{\lambda_{i}}} ; k_{2}=\frac{1}{\frac{1}{\alpha_{e}}+\sum_{e=1}^{n} \frac{\delta_{e}}{\lambda_{e}}},
$$

where $\alpha_{i}, \alpha_{e}$ - heat transfer coefficients; $\sum_{i=1}^{n} \frac{\delta_{i}}{\lambda_{i}}, \sum_{i=1}^{n} \frac{\delta_{e}}{\lambda_{e}}-$ the sum of the thermal resistances for the inner and outer parts of the enclosing structures.
The heat flow by radiation between surfaces with allowance for the Stefan-Boltzmann equation:

$$
Q_{1-2}=\varphi_{1-2} \varepsilon_{1-2} c_{0}\left[\left(\frac{T_{1}(x)+273}{100}\right)^{4}-\left(\frac{T_{2}(x)+273}{100}\right)^{4}\right] d x \text {, }
$$

where $c_{0}$ - the emissivity of an absolutely black body, $\mathrm{W} / \mathrm{m}^{2}$; $\varphi_{1-2}-$ configuration coefficient; $\varepsilon_{1-2}-$ absorption coefficient.

For surfaces $p_{1}$ and $p_{2}$ :

$$
\varepsilon_{1-2}=\frac{1}{\frac{1}{\varepsilon_{1}}+\frac{1}{\varepsilon_{2}}-1}
$$

The coefficient $\varphi_{1-2}=1[13,15]$, that is, the heat flow from radiation from a heated surface to a less heated surface, is transmitted only to opposite surfaces.

Taking into account equations (8) and (9), and also (6), (7) let's obtain:

- the equation of the thermal balance of the surface $p_{1}$ :

$$
\begin{aligned}
& k_{1}\left(T_{i}-T_{1}(x)\right) d x= \\
& =\varepsilon_{1-2} c_{0}\left[\left(\frac{T_{1}(x)+273}{100}\right)^{4}-\left(\frac{T_{2}(x)+273}{100}\right)^{4}\right] d x+ \\
& +h c_{1}\left(T_{1}(x)-T a_{1}(x)\right) d x
\end{aligned}
$$

- the equation of the thermal balance of the surface $p_{2}$ :

$$
\begin{aligned}
& \varepsilon_{1-2} c_{0}\left[\left(\frac{T_{1}(x)+273}{100}\right)^{4}-\left(\frac{T_{2}(x)+273}{100}\right)^{4}\right]= \\
& =h c_{2}\left(T_{2}(x)-T a_{2}(x)\right) d x+k_{2}\left(T_{2}(x)-T_{e}\right) d x .
\end{aligned}
$$

The third equation, supplementing the equations of thermal balances, is the equation of air movement in the ES channel, which is the balance of total pressure losses and total pressure.

In the case of a vertical enclosing structure, the total pressure is equal to the sum of gravity pressure and wind pressure:

$$
\left(\sum \zeta+\lambda_{f} \frac{h}{D_{h}}\right){\frac{v_{m}^{2}}{2_{m}}}_{m}=\left(n_{1}-n_{2}\right){\frac{v_{w}^{2}}{2_{e}}}_{e}++H g\left(\rho_{e}-\rho_{m}\right) .
$$

For horizontal construction:

$$
\left(\sum \zeta+\lambda_{f} \frac{h}{D_{h}}\right) \frac{v_{m}^{2}}{2 \rho_{m}}=\left(n_{1}-n_{2}\right) \frac{v_{w}^{2}}{2 \rho_{e}},
$$

where $\sum \zeta$ - the sum of local resistances; $\lambda_{f}-$ coefficient of resistance $\left(\lambda_{f}=f(R e)\right) ; h$ - the thickness of the air layer; $H$ - the distance between the holes for the air inlet and outlet; $D_{h}$ - the average width of the air layer; $v_{w}$ - wind velocity; $\rho_{m}$ - average air density in the ES; $\rho_{e}$ - density of outside air; $g$ - acceleration; $n_{1}, n_{2}$ - aerodynamic coefficients at the inlet and outlet of the channel; $v_{m}$ - average air velocity.

If the air inlet and outlet for air are different in size from the intersection of the air channel, then the local pressure loss in the holes must be attributed to the velocity in the hole $v_{0}$. In this case, it is necessary to add 
to the left-hand side of equations (19) and (20) local pressure losses in the holes:

$$
P_{o t v}=\sum \zeta_{0} \frac{v_{0}^{2}}{2} \rho_{0},
$$

where $\sum \zeta_{0}$ - the sum of the pressure losses in the holes; $v_{0}$ - air velocity in the hole.

Mathematical model of the heat exchange process in the ES for the cold period in the general form:

$$
\left\{\begin{array}{l}
k_{1}\left(T_{i}-T_{1}(x)\right) d x= \\
=\varepsilon_{1-2} c_{0}\left[\left(\frac{T_{1}(x)+273}{100}\right)^{4}-\left(\frac{T_{2}(x)+273}{100}\right)^{4}\right] d x+ \\
+h c_{1}\left(T_{1}(x)-T a_{1}(x)\right) d x, \\
\varepsilon_{1-2} c_{0}\left[\left(\frac{T_{1}(x)+273}{100}\right)^{4}-\left(\frac{T_{2}(x)+273}{100}\right)^{4}\right] d x= \\
=h c_{2}\left(T_{2}(x)-T a_{2}(x)\right) d x+k_{2}\left(T_{2}(x)-T_{e}\right) d x, \\
h c_{1}\left(T_{1}(x)-T a_{1}(x)\right) d x=c G_{1} d T a_{1}, \\
h c_{2}\left(T_{2}(x)-T a_{2}(x)\right) d x=c G_{2} d T a_{2}, \\
\left(\sum \zeta+\lambda_{f} \frac{h}{D_{h}}\right) \frac{v_{m}^{2}}{2}=\left(n_{1}-n_{2}\right) \frac{v_{w}^{2}}{2}+H g\left(\rho_{e}-\rho_{m}\right) .
\end{array}\right.
$$

The model has four unknown functions $T_{1}(x), T_{2}(x)$, $T a_{1}(x), T a_{2}(x)$. In addition, the unknown parameter is the air velocity in the channel. Thus, the number of equations is equal to the number of unknowns. To simplify the solution of the model equations, let's accept the following assumptions:

- the surface temperature does not depend on the variable $x$;

- heat transfer coefficients do not change along the length of the air channel.

In the formulation of the mathematical model, let's also assume that the airflow $G$ in the roof space is conditionally divided into two flows:

- the first moves near the inner surface $G_{1}$;

- the second air flow moves near the outer surface $\left(G_{1}=G_{2}=G / 2\right)$.

$$
\left\{\begin{array}{l}
k_{1}\left(T_{i}-T_{1}(x)\right) d x= \\
=\varepsilon_{1-2} c_{0}\left[\left(\frac{T_{1}(x)+273}{100}\right)^{4}-\left(\frac{T_{2}(x)+273}{100}\right)^{4}\right] d x+ \\
+h c_{1}\left(T_{1}(x)-T a_{1}(x)\right) d x, \\
\varepsilon_{1-2} c_{0}\left[\left(\frac{T_{1}(x)+273}{100}\right)^{4}-\left(\frac{T_{2}(x)+273}{100}\right)^{4}\right] d x= \\
=h c_{2}\left(T_{2}(x)-T a_{2}(x)\right) d x+k_{2}\left(T_{2}(x)-T_{e}\right) d x, \\
T a_{1}(x)=T_{1}-\frac{T_{1}-T_{e}}{e^{\frac{h c_{1}}{c G}}}, \\
T a_{2}(x)=T_{2}-\frac{T_{2}-T_{e}}{\frac{h c_{2}}{v_{G}} x}, \\
\left(\sum \zeta+\lambda_{f} \frac{h}{D_{h}}\right) \frac{v_{m}^{2}}{2}=\left(n_{1}-n_{2}\right) \frac{v_{w}^{2}}{2}+H g\left(\rho_{e}-\rho_{m}\right) .
\end{array}\right.
$$

On the basis of the analysis of design methods for the ES design, it can be stated that the classical method for estimating heat exchange processes is based on the equations for the heat balance of air for an infinitesimal volume $d x$ (1). When equation (1) is used, it is impossible to take into account the distribution of radiant and convective heat flows, and also to estimate the effect of energy losses.

It can also be argued that the heat exchange process, given the shortcomings of existing methods of calculation, is better represented as a system of equations (18), (19).

\section{SWOT analysis of research results}

Strengths. The proposed mathematical model of the process of heat exchange in the ES for the cold period will eliminate the inaccuracy in the calculation of heat exchange processes, as well as create appropriate methods for designing energy-efficient enclosing structures.

Weaknesses. When equation (1) is used, it is impossible to take into account the distribution of radiant and convective heat flows, and also to estimate the effect of energy losses.

Opportunities. The study can be used to develop incentives to reduce heat losses through:

- walls;

- reduction of the difference in temperatures of the

internal and external air;

- allowance for the distribution of radiant and convective heat flows.

In the future, it is planned to conduct experimental studies of heat exchange processes in air in ventilated channels and, on the basis of the obtained data, to create the corresponding equations that specified the proposed mathematical model.

Threats. Much of the heat loss in homes during the heating season is due to the difference in the temperatures of the indoor and outdoor air (transmission heat losses through the outer enclosing structures).

\section{Conclusions}

1. It is determined that the main element of open ventilated channels is the outer wall of the house, in which the air layer is between the insulation layer and the facade slabs. The movement of outdoor air in the ES along the wall of the house leads to heat loss, but air in the ventilated layer will prevent the formation and accumulation of condensate. This will allow in winter to maintain the thermal properties of the outer layer of insulation at home, reduce the cost of heat for heating and prevent the formation and development of fungal mold. During the summer period, the room will be warmed up less, due to the cooling of the wall with air intake.

2. In the conducted research it is possible to establish the main causes that lead to unjustifiably large heat losses in the housing and communal sector, which include:

- imperfection of existing building structures;

- the lack of individual meters and systems for regu-

lating energy consumption.

3. The peculiarities of heat exchange processes in building structures with ventilated channels are studied. On the basis of the analysis of design methods for the ES design, it can be stated that the classical method for estimating heat exchange processes is based on the equations 
for the heat balance of air for an infinitesimal volume (1). When equation (1) is used, it is impossible to take into account the distribution of radiant and convective heat flows, and also to estimate the effect of energy losses. It can also be argued that the heat exchange process, given the shortcomings of existing methods of calculation, is better represented as a system of equations (18), (19).

\section{References}

1. Dolinskyi A. A. Komunalna teploenerhetyka Ukrainy: stan, problemy, shliakhy modernizatsii. Kyiv, 2007. 827 p.

2. Dolinskyi A. A., Basok B. I. Stvorennia eksperymentalnoho enerhoefektyvnoho budynku pasyvnoho typu: proceedings // Enerhetychna bezpeka na transporti: pidvyshchennia enerhoefektyvnosti, znyzhennia zalezhnosti vid pryrodnoho hazu. Kyiv, 2014. P. 26-30.

3. Stvorennia eksperymentalnoho enerhoefektyvnoho budynku pasyvnoho typu «nul enerhii» / Honcharuk S. M. et al. // Promyslova teplotekhnika. 2014. Vol. 36, No. 3. P. 88-95.

4. Nedbaylo A. N. Osobennosti teploperedachi cherez mnogosloynuyu ograzhdayushhuyu konstruktsiyu v nestatsionarnom rezhime // Keramika: nauka i zhizn. 2014. No. 1 (22). P. 4-9.

5. Stepanenko O. I., Dubrovska V. V. Pasyvnyi budynok - shliakh do efektyvnoho vykorystannia enerhii // Enerhetyka: ekonomika, tekhnolohii, ekolohiia. 2014. No. 3. P. 56-58.

6. Ventiliruemye stenovye paneli / Belyaev V. S. et al. // Sel'skoe stroitel'stvo. 1984. No. 1. P. 12-14.

7. Bajc T., Todorovic M. N., Svorcan J. CFD analyses for passive house with Trombe wall and impact to energy demand Energy and Buildings. 2015. Vol. 98. P. 39-44. doi:10.1016/ j.enbuild.2014.11.018
8. Dynamic thermal performance simulation of an improved passive solar house with Trombe wall / Jinling Z. et al. // Proceedings of ISES World Congress 2007 (Vol. I-Vol. V). 2007. Vol. 1. P. 2234-2237. doi:10.1007/978-3-540-75997-3 451

9. Heat transfer in buildings: application to air solar heating and Trombe wall design / Boyer H. et al. // Evaporation, condensation and heat transfer. 2011. P. 227-244. doi:10.5772/23025

10. Lobna M., Dehmani L. A numerical study of heating and cooling by a Trombe wall in Tunisia // The fifth International Renewable energy congress. Tunisia: Hammamet, 2014. doi:10.1109/irec.2014.6826940

11. An innovative Trombe wall as a passive heating system for a building in Athens-A comparison with the conventional Trombe wall and the insulated wall / Bellos E. et al. // Energy and Buildings. 2016. Vol. 133. P. 754-769. doi:10.1016/ j.enbuild 2016.10.035

12. Yin Z. Simulation and Modification of a Composite Trombe Wall to Adapt to the Climate in Victoria, Canada. University of Victoria, 2016. 65 p.

13. Bogoslovskiy V. N. Stroitel'naya teplofizika. Moscow: Vysshaya shkola, 1982. $415 \mathrm{p}$

14. Fokin K. F. Stroitel'naya teplotekhnika ograzhdayushhikh chastey zdaniy / ed. by Tabunshhikov Yu. A., Gagarin V. G. Moscow: AVOK-Press, 2006. 256 p.

15. Klemm P. Zahalne budivnytstvo. Budivelna fizyka. Vol. 2. Warsaw: Arkadii, 2006.

16. Mikheev M. A., Mikheeva I. M. Osnovy teploperedachi. Moscow: Energiya, 1977. 344 p.

Lymarenko Oleksiy, Lecturer, Gogol Mirgorod Art and Industrial College of the Poltava National Technical Yuriy Kondratyuk University, Mirgorod, Ukraine, e-mail: tonus821@gmail.com, ORCID: http://orcid.org/0000-0002-1714-4508 